\title{
Development of Urea Biosensor Based on Immobilized Urease in Chitosan Cryogel
}

\author{
Zusfahair*, Dian Riana Ningsih, Elok Dwi Putri Lestari, Amin Fatoni. \\ Department of Chemistry, Faculty of Mathematics and Natural Sciences, \\ Jenderal Soedirman University, Purwokerto 53123, Indonesia. \\ *Corresponding author email: zusfahair@gmail.com
}

Received: 30 Mar 2019; Accepted: 29 May 2019; Available online: 5 Jun 2019

\begin{abstract}
The development of biosensors using biological components has an important role in detecting the disease early because it has good selectivity and accuracy. In this study, a biosensor which made is a urea biosensor, based on immobilization urease in chitosan using adsorption techniques, to measure urea levels by colorimetric analysis with bromothymol blue (BTB) as an indicator. The purpose of this study was to find out how to measure urea levels using biosensors based on urease immobilization in chitosan and find out the biosensor performance including optimum enzymatic reaction time, linearity, the limit of detection, repetition, and determination of disrupting compounds. The study began with the making of an immobilization supporting matrix using chitosan which was made in the form of cryogel through an ionic gelation process which adsorbs the urease enzyme. Cryogel urease catalyzes the hydrolysis of urea into $\mathrm{NH}_{4}{ }^{+}$and $\mathrm{CO}_{2}$. The reaction product was added with the BTB indicator, and the color change formed was measured using a spectrophotometer. The results showed that the performance of urea biosensors was good enough for urea level detection systems by producing enzymatic reaction times at 15 minutes, linearity at 0.9951 , detection limit at $0.018 \mathrm{mM}$, not affected by the addition of $0.05 \mathrm{mM}$ ascorbic acid and $0.4 \mathrm{mM}$ uric acid. This urea biosensor can be used up to 5 repetitions.
\end{abstract}

Keywords: biosensor, bromothymol blue (BTB), cryogel, chitosan, urease

\section{INTRODUCTION}

Urea is the final product of the nitrogen cycle in the liver. Urea in blood or urine is an important marker for the diagnosis of kidney disease. The normal urea levels in serum are about $2.5 \mathrm{mM}$ to $6.7 \mathrm{mM}$ (Saeedfar, Heng, Ling, \& Rezayi, 2013), In patients with kidney failure, the urea levels in serum could increase to $50-150 \mathrm{mM}$ (Velychko et al., 2016). Kidney disease is one of the common chronic diseases in Indonesia. Therefore, it is important to develop or improve the urea detection methods as part of the preventive strategy of early detection of kidney failure. Urea concentration in blood could be determined in various methods such as chromatographic (Wang et al., 2016), spectrophotometric (Fuertes, Pérez, \& Alonso, 2004), colorimetric (Fatoni, Anggraeni, \& Zulhidayah, 2019) and electrochemical (Tiwari, Aryal, Pilla, \& Gong, 2009). The recent study of urea determination was the use of biological sensing element, such as enzyme to detect the urea concentration.

The use of biosensor to detect analyte is interesting to be developed because it can determine a low concentration of analytes (Debataraja \& Soelaiman, 2011). The continued improvement of biosensor development mainly due to increase sensitivity, selectivity, stability, and effectiveness. Urease is most commonly used as the biosensing element in the urea biosensor study. Urease could be obtained from microorganism (Smith, King, \& Goodman, 2009) or beans, such as asparagus bean (Zusfahair, Ningsih,
Fatoni, \& Santri, 2018a); (Zusfahair, Ningsih, Fatoni, \& Santri, 2018b), black-eyed pea (Zusfahair, Ningsih, Fatoni, \& Putri, 2018), cotton seed (Menegassi et al., 2008) and jack bean (Follmer, Wassermann, \& Carlini, 2004).

The development of supporting matrices for enzyme immobilization is also an important aspect in the biosensor studies since it related to the enzyme activities and reusability. The previous study has been reported of urease-based urea biosensors using nylon membranes as supporting material for enzyme immobilization (Verma, Kumar, \& Sachin, 2012), Another urease-based biosensor were used immobilized urease on $\mathrm{ZnO}$ nanoparticles (Eghbali \& Farahbakhsh, 2015) and modified fullerene nanomaterial (Saeedfar et al., 2013). In this paper, urease was immobilized on a chitosan cryogel. The cryogel provides a large surface area resulting in biosensors with high sensitivity and high selectivity.

The development of urea biosensors in this work was using the colorimetric method for simpler diagnosis system. The colorimetric analysis of urea detection was based on the hydrolysis of urea by urease to produce ammonia, which was generally measured by Nessler reagent. However, the Nessler reagent is relatively expensive and long analysis times needed. In this study, the indicators of bromothymol blue (BTB) was chosen to identify color changes urease reaction. The BTB indicator will produce blue to green in alkaline solutions and yellow in acidic solutions (Shimada \& Hasegawa, 2017). 
The urea hydrolysis produces $\mathrm{CO}_{3}{ }^{-2}$ and $2 \mathrm{NH}_{4}{ }^{+}$would change BTB to alkaline form that could be measured at $620 \mathrm{~nm}$ using spectrophotometer (Xie \& Suleiman, 1990). The absorbance that obtained was then used to make the calibration curve and study the analytical performances such as optimum time, linearity, the limit of detection, repetition, and selectivity.

\section{EXPERIMENTAL SECTION \\ Materials and Instruments}

Centrifuge (Quantum), UV-Vis spectrophotometer (Shimadzu UV-1800), Asparagus bean (Vigna unguiculata Subsp. Sesquipedalis (L.) Verdc) obtained from the local market in Purwokerto. Acetone, urea, bromothymol blue, acetic acid, chitosan, sodium tripolyphosphate, and ammonium hydroxide used were analytical grade, purchased from Merck (Germany).

Isolation of urease from asparagus bean (Zusfahair, Ningsih, Fatoni, \& Santri, 2018b)

Asparagus bean seeds of $100 \mathrm{~g}$ were soaked in tap water for 6 hours. The wet seed was then germinated in the dark room for eight days. The germinated seed of $10 \mathrm{~g}$ was mashed in cool condition, dissolved in $25 \mathrm{~mL}$ of cooled acetone, and homogenized for $3 \mathrm{~h}$. The suspension was filtered, continued by at for $15 \mathrm{~min}$ at $7000 \mathrm{rpm}$ in cool condition. The supernatant obtained was the urease crude extract used for further study.

Immobilization of urease (Fatoni, Anggraeni, \& Dwiasi, 2016).

A chitosan solution of $0.6 \%(\mathrm{~b} / \mathrm{v})$ was prepared by dissolving $0.012 \mathrm{~g}$ chitosan into $2 \mathrm{~mL}$ of acetic acid $1 \%$ $(\mathrm{v} / \mathrm{v})$. The mixture was then dropped using a 100-1000 uL micropipette into $1 \%(\mathrm{w} / \mathrm{v})$ of sodium tripolyphosphate solution, allow for 30 minutes to get the chitosan beads. Chitosan beads were then stored at $-20{ }^{\circ} \mathrm{C}$ for 6 hours to make chitosan bead cryogel. The bead was then thawed at $40 \mathrm{C}$ for $1 \mathrm{~h}$, and rinse with distilled water to remove the remaining solvent in the bead pores. The chitosan cryogel formed from $1 \mathrm{~mL}$ of chitosan solution was soaked in 2 $\mathrm{mL}$ of the urease crude enzyme and stored at $4{ }^{\circ} \mathrm{C}$ for 12 hours to complete the enzyme immobilization process. Immobilized urease in chitosan cryogel bead was then used for urea determination.

\section{Biosensor Testing \\ Determination of maximum wavelength}

The urea detection was started by searching the maximum wavelength of the standard solution of ammonium hydroxide, as a simulated enzymatic reaction product, using various concentrations of $0.01 ; 0.02 ; 0.03$; 0.04 and $0.05 \mathrm{mM}$. Each $3 \mathrm{~mL}$ of ammonium hydroxide solution was added a BTB indicator of $150 \mu \mathrm{L}$. The solutions were then scan using spectrophotometer for 400 to $700 \mathrm{~nm}$ wavelength. The standard curve was made of the increase in absorbance with the ammonium hydroxide concentration.

\section{Optimization of enzymatic reaction time}

Urea detection using immobilized urease was performed by mixing $3 \mathrm{~mL}$ of urea with urease chitosan cryogels at various enzymatic reaction times: $5,10,15$, $20,25,30,35$ and 40 minutes. The solution was put into the test tube after the enzymatic reaction was completed and added with the $150 \mu \mathrm{L}$ BTB indicator. In this test, distilled water was added in urease chitosan cryogel and used as a blank. The absorbance of the solution was measured using a UV-Vis spectrophotometer at the maximum wavelength. The difference in absorbance of the sample solution and blank is plotted into a graph of the enzymatic reaction time.

\section{Operational stability}

The stability of immobilized urease in the urea biosensor was performed by repeatedly analysis of urea standard solutions using the same urease chitosan cryogel beads. The beads were rinsed with distilled water before reuse for the next analysis. The urea determination was continuously performed until the remaining activity of $50 \%$ compares to the first use of the beads.

\section{Analytical performance of the urea biosensor \\ Linear range}

Linear range test was carried out by analyzing standard urea solution in various concentrations of 0.1 ; $0.5 ; 1 ; 3 ; 5 ; 7 ; 10$ and $15 \mathrm{mM}$. The urea solutions were reacted with urease chitosan cryogels, reacted at optimum incubation time followed by adding the BTB indicator to the reaction results. The increasing absorbance with the urea concentration was then plotted into a standard curve. Limit of detection dan Limit of Quantification

Limit of detection (LOD) and Limit of Quantification (LOQ) was calculated from the linear equation using the following formula the formula:

$$
\begin{gathered}
S D=\sqrt{\frac{\sum(Y-Y i)^{2}}{n-2}} \\
L O D=\frac{3 x S D}{\text { slope }} \\
L O Q=\frac{10 x S D}{\text { slope }}
\end{gathered}
$$

SD: Standard deviation

Y: The absorbance of sample

Yi: The average of samples' absorbance

$\mathrm{n}$ : Number of samples

LOD: Limit of Detection

LOQ: Limit of Quantification

Reproducibility

The reproducibility of the urea biosensor was tested by analyzing the urea sample in the same concentration using different immobilized urea chitosan cryogel preparation. Ten different immobilized urease was used to determine the standard urea solution; then the results were calculated to get the coefficient of a variant. The standard deviation (SD), relative standard deviation (\% RSD), or the coefficient of a variant $(\mathrm{CV})$ were calculated with the following equation:

$$
\begin{gathered}
S D=\sqrt{\frac{\sum(x-\bar{x})^{2}}{n-1}} \\
\% R S D=\frac{S D}{\bar{x}} \times 100 \%
\end{gathered}
$$


Information:

$$
C V=\frac{S D}{\bar{x}} \times 100 \%
$$

SD: Standard Deviation

$\mathrm{X}$ : the value of data from the sample

$\bar{x}:$ the average of samples

$\mathrm{N}$ : the number of samples

RSD: Relative Deviation Standard

CV: Coefficient of Variation

The resulting CV was then compared to the Horwitz ratio (HorRat) value from the following equation:

$$
\begin{gathered}
\text { Theoretical } C V=2^{(1-0,5 \log C)} \\
\text { HorRat }=\frac{C V \text { experimental }}{C V \text { theoretical }}
\end{gathered}
$$

\section{Selectivity study}

The selectivity of the urea biosensor was tested using the common interferences found in the blood. The selectivity was performed by adding ascorbic acid 0.05 $\mathrm{mM}$ and $0.4 \mathrm{mM}$ uric acid into each $3 \mathrm{mM}$ urea solution. The urea solution with the interferences was then analyzed using the same procedure of urea determination using developed urea biosensor.

\section{RESULTS DAN DISCUSSION Urease immobilization}

The chitosan cryogel was prepared by dissolving chitosan into the acetic acid solution. The acetic acid was chosen because chitosan dissolves easily in aqueous acid solution at $\mathrm{pH} 5-6$. The mixture was dropped in the TPP solution using micropipette to make the chitosan beads by the ionic gelation method. The beads developing was by electrostatic interactions between the chitosan positive charge and the negative charge of the polyanion, which acts as a crosslinker. The advantage of the ionic gelation method is that it is simple, could be performed at room temperature and no organic solvents or toxic crosslinkers needed (Sakloetsakun, Perera, Hombach, Millotti, \& Bernkop-schnürch, 2010). The equation of ionic cross bond formation between chitosan TPP (Kurniasih, Riyani, Setyaningtyas, \& Sufyana, 2018).

The chitosan beads were then stored at $-20{ }^{\circ} \mathrm{C}$ to freeze the solvent. The pore beads formed when the chitosan bead was thawed at $4{ }^{\circ} \mathrm{C}$, to allow the melting solvent remove from the chitosan beads, leave a porous structure of chitosan cryogel beads. Temperature to melt the solvent ice crystals trapped in the matrix (Figure 2). A previos study showed the pore size of chitosan cryogel beads was about 50-100 micron (Fatoni et al., 2016).

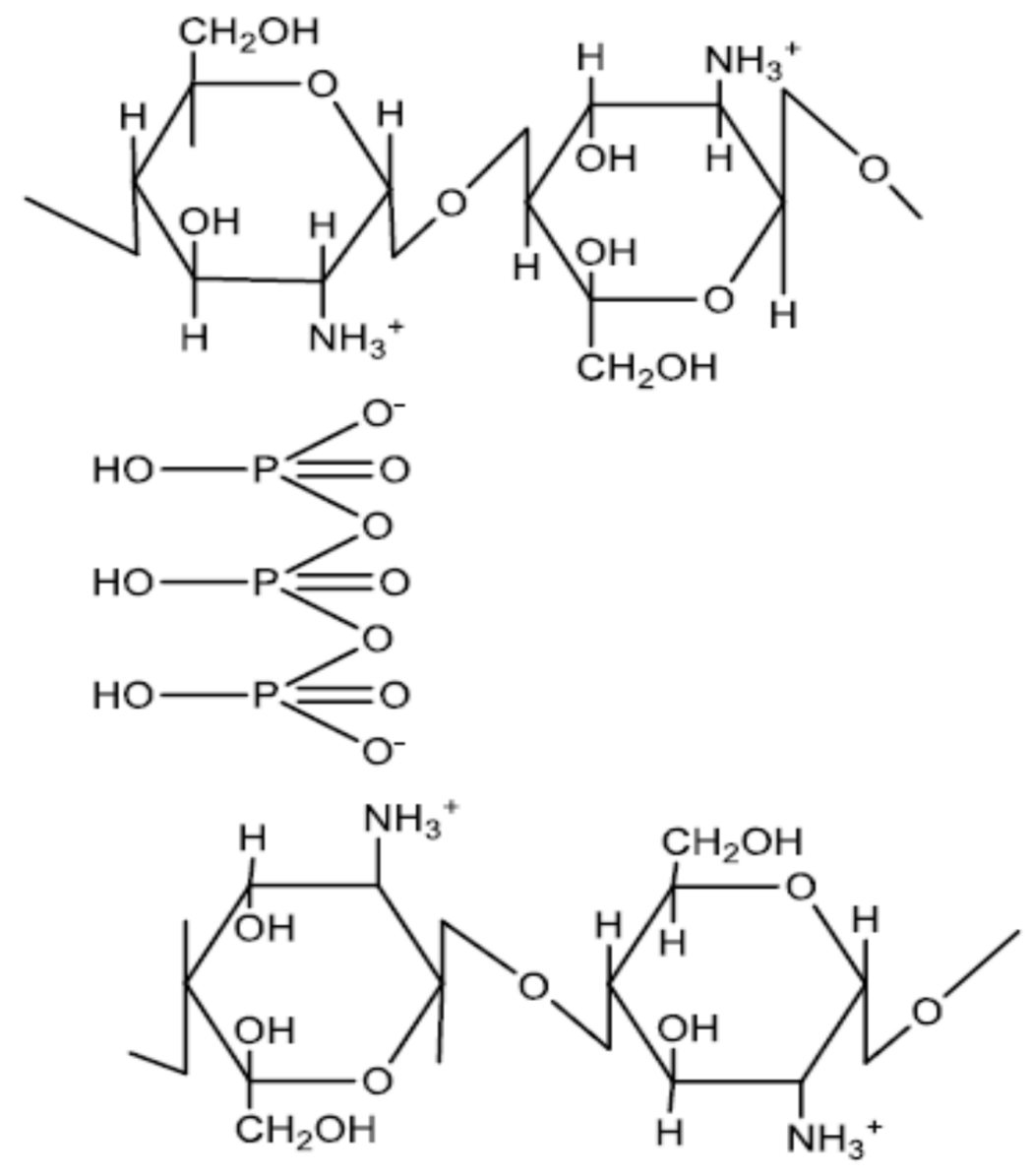

Figure 1 The cross bond reaction between chitosan TPP (Kurniasih et al., 2018). 

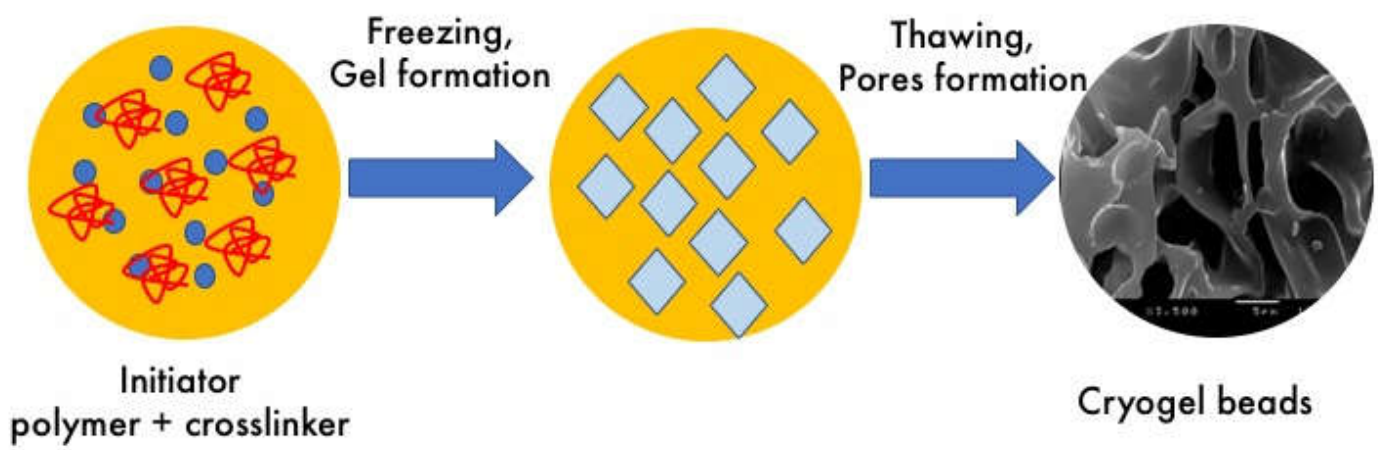

Cryogel beads

Figure 2. The porous cyrogel beads formed during the freezing and thawing process.

\section{Biosensor Testing}

\section{Determination of maximum wavelength}

In this study, determination of maximum wavelength was conducted using ammonium hydroxide solution. Ammonium hydroxide is a product of the reaction between urea and urease enzyme. The reactions are as follows (Mobley, Mendz, \& Hazell, 2001):

$$
\begin{gathered}
\mathrm{H}_{2} \mathrm{~N}-\mathrm{CO}-\mathrm{NH}_{2} \stackrel{\text { urease }}{\longrightarrow} \mathrm{NH}_{3}+\mathrm{H}_{2} \mathrm{~N}-\mathrm{C}(\mathrm{O}) \mathrm{OH} \\
\mathrm{H}_{2} \mathrm{~N}-\mathrm{C}(\mathrm{O}) \mathrm{OH}+2 \mathrm{H}_{2} \mathrm{O} \rightarrow \mathrm{NH}_{3}+\mathrm{H}_{2} \mathrm{CO}_{3}+
\end{gathered}
$$

In aqueous solution, the released carbonic acid and two molecules of ammonia are equilibrium with their deprotonated and protonated forms.

$$
2 \mathrm{NH}_{3}+2 \mathrm{H}_{2} \mathrm{O} \leftrightarrow 2 \mathrm{NH}_{4}^{+}+2 \mathrm{OH}^{-}
$$

The reaction would increase the $\mathrm{pH}$, and the color change with the $\mathrm{pH}$ due to the indication addition was measured using UV-Vis spectrophotometer, showed a maximum wavelength of $616 \mathrm{~nm}$ (Figure 3).
BTB is widely used as an indicator of the acid-base which is a member of sulfonphthalein dyes. BTB shows yellow in a weak acid solution and blue via green with the increase of $\mathrm{pH}$ (Figure 4).

Greenish colors appear in BTB solutions at almost neutral $\mathrm{pH}$ (about 7). Originally the greenish BTB color is a mixture of yellow and blue forms. Therefore, BTB is one of the most suitable indicators and is useful for distinguishing the acidity, neutrality, and alkalinity of aqueous solutions. Indicator compounds that change the color depending on the $\mathrm{pH}$ of the environment are called halochromic materials. At low $\mathrm{pH}$, the yellow form shows maximum absorption at around $433.0 \mathrm{~nm}$; whereas the blue form shows a peak at around $615.5 \mathrm{~nm}$ in high $\mathrm{pH}$. The isosbestic point appears to be recognized at $324.5 \mathrm{~nm}$ and $498.5 \mathrm{~nm}$, which implies that spectral variations will be easily explained by only two chemical constituents (Shimada \& Hasegawa, 2017).

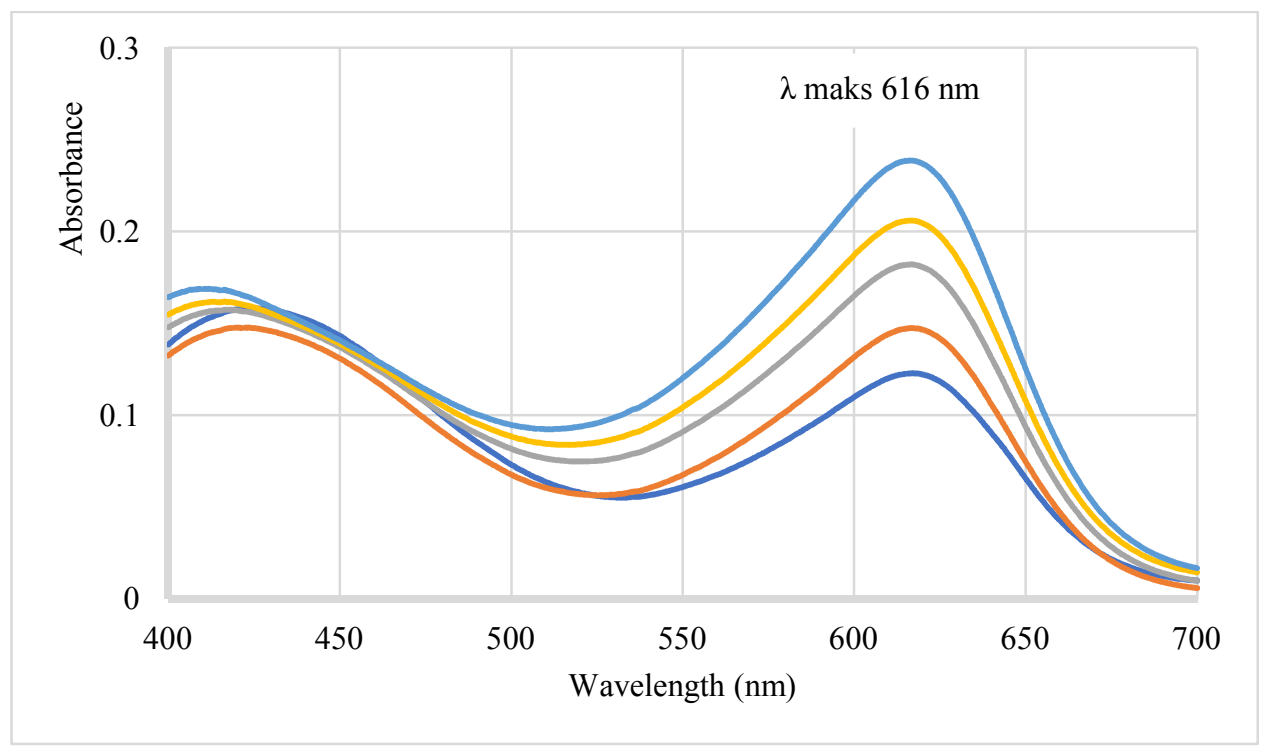

Figure 3 The Spectophotometry UV vis spectrum of ammonium hydroxide solution in various concentrations. 


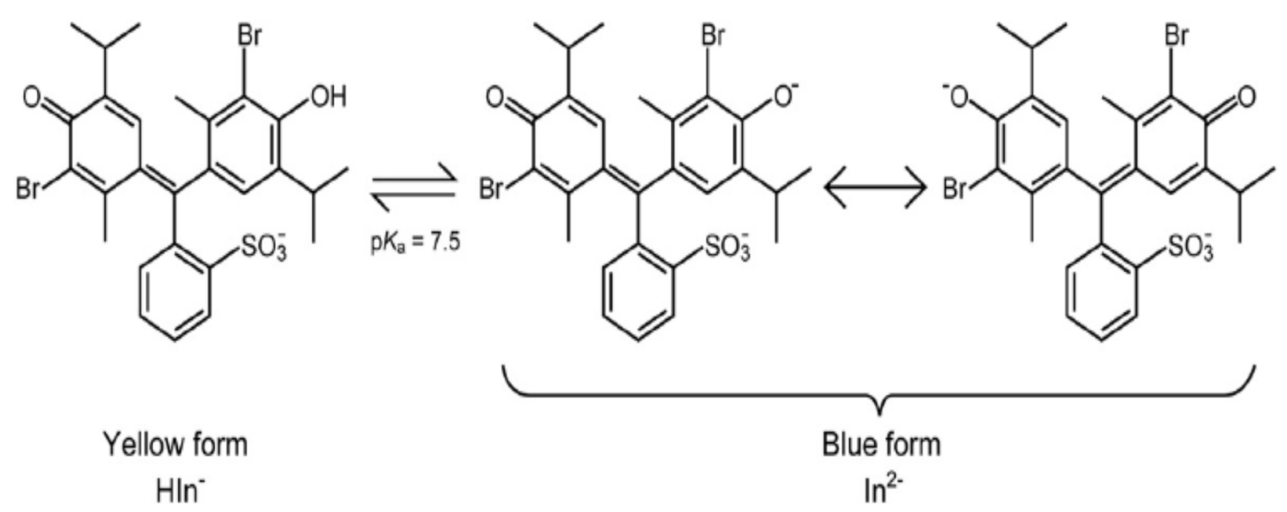

Figure 4. Structural changes in BTB from yellow form to blue with the change of $\mathrm{pH}$.

\section{Optimization of enzymatic reaction time}

The enzymatic reaction was depending on the interaction duration of enzyme and substrate. The result showed the difference absorbance from the enzymatic reaction time increased at 5 to 15 minutes and relative stable afterward. The selected reaction time was then 15 minutes for the highest result with the lowest analysis duration.

Determination of linearity, the limit of detection and limit of quantification

One of the important biosensor analytical performance was linearity. The fabricated urea biosensor was tested using a series urea standard solution to achieve the linear calibration curve. The result showed that the biosensor had linear response in the detection of urea from 1 to 10 $\mathrm{mM}$ with the regression equation of $\mathrm{y}=0.019 \mathrm{x}+0.035$ and $\mathrm{R}^{2}$ of 0.995 (Figure 6). Furthermore, the limit of detection and limit of quantification were calculated using the regression equation. The calculated LOD and LOQ were $0.018 \mathrm{mM}$ and $0.055 \mathrm{mM}$, respectively. The biosensor characteristics were determined by the detection of limit to determine the ability of detection concentration of analytes. The detection limit is the smallest number of analytes in the sample that can still be detected and still provide a significant response (Ravisankar, Navya, Pravallika, \& Sri, 2015).

\section{Operational stability}

The operational stability of immobilized urease on the chitosan cryogel beads was investigated by continuous measuring the urea solution. The beads was rinsed with phosphate buffer between the urea measurements. The result showed a decrease of the responses to $25.95 \%$ after seventh cycle usage (Figure 7). This decrease of the response may be due to the leak of the immobilized enzyme on the chitosan cryogel beads. The general disadvantage of biosensors with adsorbed enzymes was that the enzyme could slowly be released because the bonds between enzymes and supporting immobilization matrices are weak (Velychko et al., 2016). This urea biosensor stability was similar to the amylase enzyme activity that was immobilized using chitosan remained $43.3 \%$ at the fifth usage (Zusfahair, Ningsih, Kartika, Fatoni, \& Zuliana, 2017).

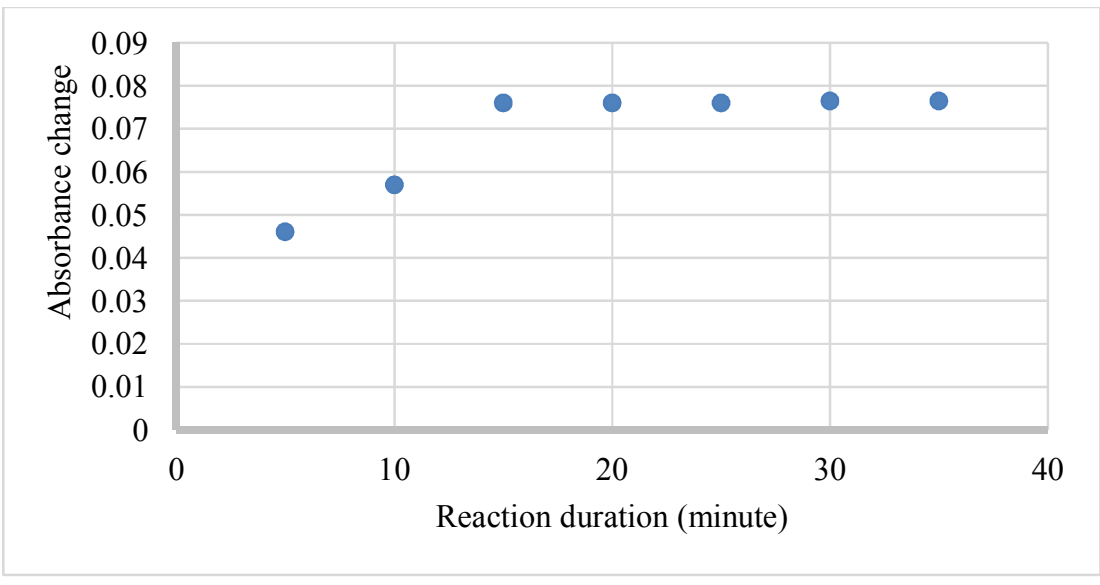

Figure 5 The effects of enzymatic reaction time on the urea detection 


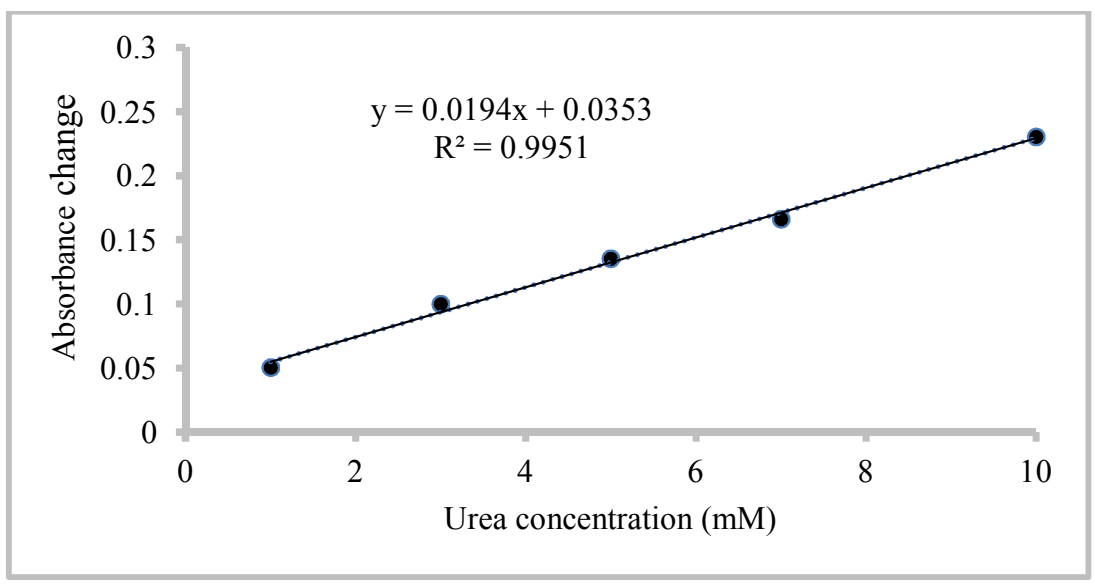

Figure 6. The urea biosensor showed linear responses to detect standard urea solution from $1 \mathrm{mM}$ to $10 \mathrm{mM}$

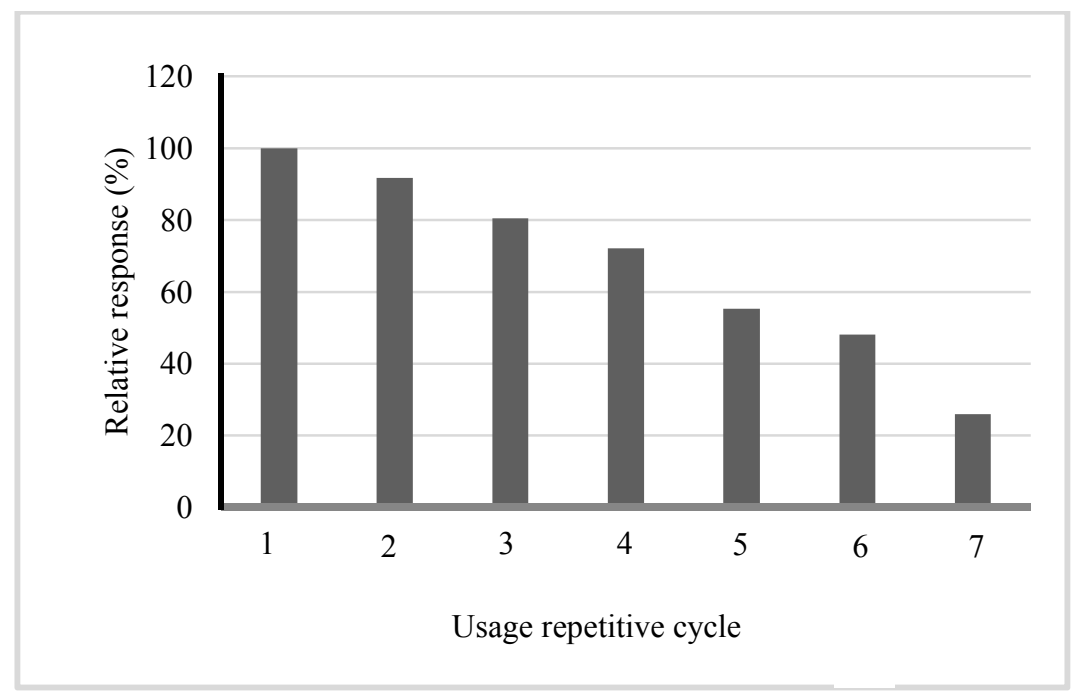

Figure 7. The repeatability study of urea biosensor to measure the urea concentration

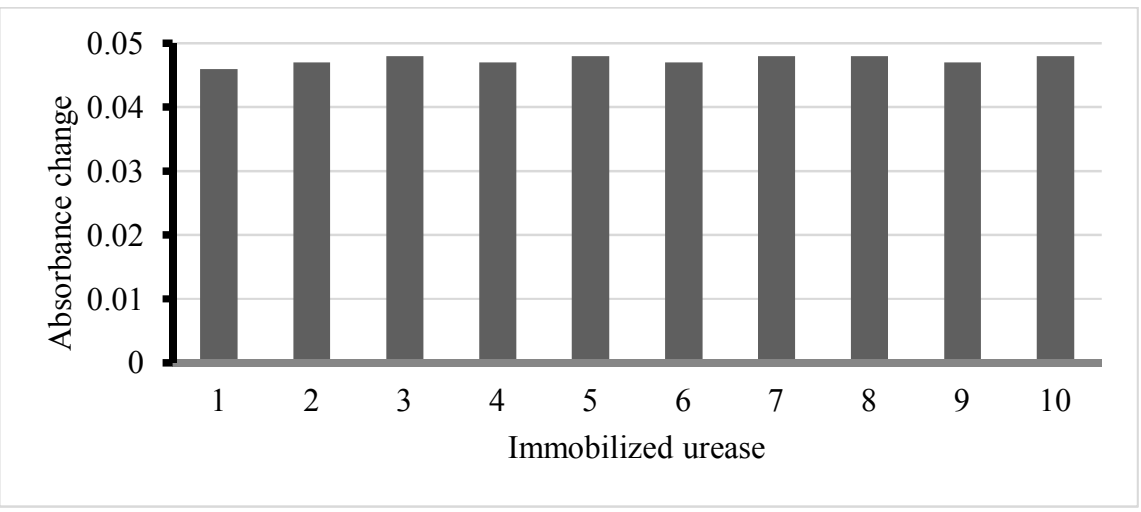

Figure 8. Reproducibility of urease immobilization on chitosan cryogel to detect standard urea solution. 


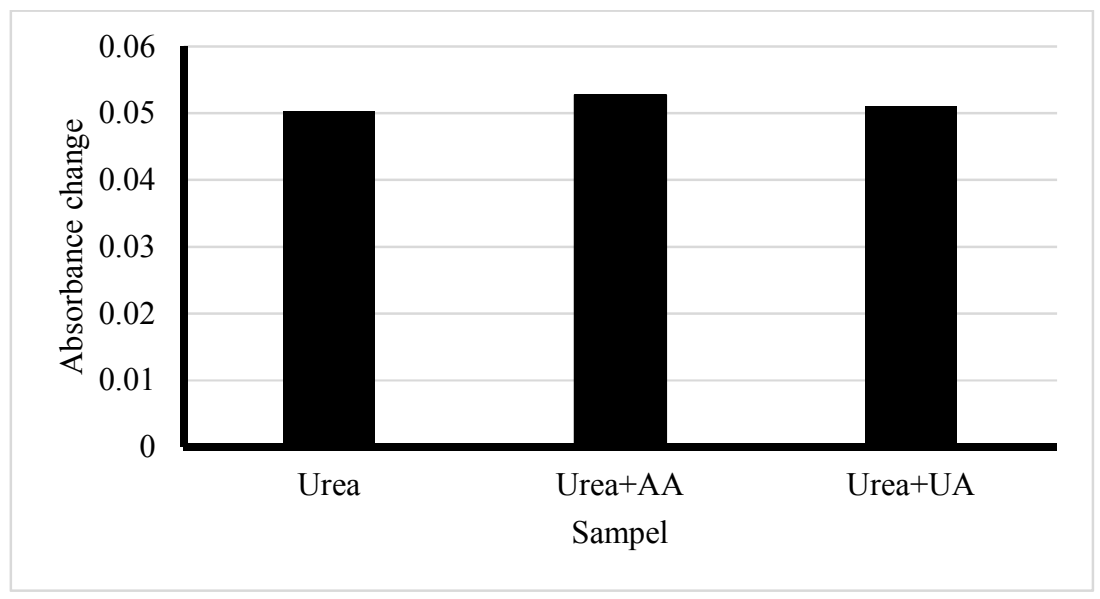

Figure 9 The effects of interferences of ascorbic acid and uric acid in urea determination by fabricated urea biosensor

\section{Reproducibility}

The reproducibility of the urease immobilization on the chitosan cryogel was investigated by measuring urea standard solution using ten different immobilized ureases. The result showed the RSD value was $1 \%$, and HorRat value was 0.125 . The acceptable reproducibility for the HorRat value should be less than 2 (Harmita, 2004). Therefore, the developed urea biosensor had a good reproducibility (Figure 8).

\section{Selectivity study}

The selectivity of urea biosensor was analyzed using common interference in the blood of uric acid and ascorbic acid. The ascorbic acid and uric acid should interfere the change of $\mathrm{pH}$ would possibly reduce the accuracy of urea determination. Levels of ascorbic acid and uric acid in normal blood are around $50 \mu \mathrm{M}$ and 380$400 \mu \mathrm{M}$, respectively (Fatoni, Numnuam, Kanatharana, \& Limbut, 2013). The results showed the addition of ascorbic acid and uric acid in the enzymatic reaction did not show a significant change in urea measurements (Figure 9). Therefore, the urea biosensor based on urease immobilization in chitosan is quite selective to determine blood urea levels.

\section{CONCLUSIONS}

Urea biosensor has been developed using immobilized urease on chitosan cryogel beads measured by a spectrophotometer. The analytical performances of urea biosensor were optimum enzymatic reaction time at 15 minutes, the linearity of $0.5-15 \mathrm{mM}$ and limit of detection of $0.0182 \mathrm{mM}$. The urea detection was not affected by the addition of $0.05 \mathrm{mM}$ ascorbic acid and 0.4 $\mathrm{mM}$ uric acid. The immobilized urease could be used up to 5 times. The urea biosensor, based on urease immobilization in chitosan has the potential to be applied in the analysis of urea in real biological samples.

\section{ACKNOWLEDGMENTS}

We would like thank to the LPPM UNSOED for the financial support of this research with the "Riset Unggulan Unsoed 2018" grant with contract number Kept. 2350/ UN23.14 / PN.01.00 / 2018.

\section{REFERENCES}

Debataraja, A., \& Soelaiman, N. F. (2011). Fabrikasi Elektroda Amperometrik Sensor dengan Metode Teknologi Screen Tension dan Deflection Thick Film. Jurnal Ilmiah Elite Elektro, 2(1), 55-60.

Eghbali, M., \& Farahbakhsh, A. (2015). Urea Biosensor Based on Immobilization of Urease on $\mathrm{ZnO}$ Nanoparticles. Oriental Journal Of Chemistry, 31(2), 1237-1242.

Fatoni, A., Anggraeni, M. D., \& Dwiasi, D. W. (2016). Simple Colorimetric Glucose Biosensor using Chitosan Cryogel Supporting Material. AIP Conference Proceedings, 1746, 20029-20029-7. https://doi.org/10.1063/1.4953954

Fatoni, A., Anggraeni, M. D., \& Zulhidayah, L. Z. (2019). Natural reagent from Secang (Caesalpinia sappan L.) heartwood for urea biosensor. In IOP Conference Series: Materials Science and Engineering (Vol. 509, p. 12010). IOP Publishing.

Fatoni, A., Numnuam, A., Kanatharana, P., \& Limbut, W. (2013). Sensors and Actuators B: Chemical A highly stable oxygen-independent glucose biosensor based on a chitosan-albumin cryogel incorporated with carbon nanotubes and ferrocene. Sensors \& Actuators: B. Chemical, 185, 725-734. https://doi.org/10.1016/j.snb.2013.05.056

Follmer, C., Wassermann, G. E., \& Carlini, C. R. (2004). Separation of jack bean (Canavalia ensiformis) urease isoforms by immobilized metal affinity chromatography and characterization of insecticidal properties unrelated to ureolytic activity. Plant Science. https://doi.org/10.1016/j.plantsci.2004.03.019

Fuertes, M. A., Pérez, J. M., \& Alonso, C. (2004). Small amounts of urea and guanidine hydrochloride can be detected by a far-UV spectrophotometric method in dialysed protein solutions. Journal of Biochemical and Biophysical Methods. https://doi.org/10.1016/j.jbbm.2004.02.001

Harmita. (2004). Petunjuk Pelaksanaan Validasi dan Cara Perhitungannya. Majalah Ilmu Kefarmasian, I(3), 117-135. 
Kurniasih, M., Riyani, K., Setyaningtyas, T., \& Sufyana, I. (2018). Adsorpsi Ion Ni(II) Menggunakan Crosslink Kitosan Tripolifosfat Adsorption of Ni(II) Ions Using Crosslink of Chitosan Tripolyphosphate. Jurnal Rekayasa Kimia Dan Lingkungan, 13(2), 174-181.

Menegassi, A., Wassermann, G. E., Olivera-Severo, D., Becker-Ritt, A. B., Martinelli, A. H. S., Feder, V., \& Carlini, C. R. (2008). Urease from cotton (Gossypium hirsutum) seeds: Isolation, physicochemical characterization, and antifungal properties of the protein. Journal of Agricultural and Food Chemistry. https://doi.org/10.1021/jf0735275

Mobley, H. L. T., Mendz, G. L., \& Hazell, S. L. (2001). Restriction and Modification Systems--Helicobacter pylori: Physiology and Genetics. ASM press.

Ravisankar, P., Navya, C. N., Pravallika, D., \& Sri, D. N. (2015). A Review on Step-by-Step Analytical Method Validation. IOSR Journal Of Pharmacy, 5(10), 7-19.

Saeedfar, K., Heng, L. Y., Ling, T. L., \& Rezayi, M. (2013). Potentiometric Urea Biosensor Based on an Immobilised Fullerene-Urease Bio-Conjugate. Sensors, 13, 16851-16866. https://doi.org/10.3390/s131216851

Sakloetsakun, D., Perera, G., Hombach, J., Millotti, G., \& Bernkop-schnürch, A. (2010). The Impact of Vehicles on the Mucoadhesive Properties of Orally Administrated Nanoparticles: a Case Study with Chitosan-4-Thiobutylamidine Conjugate. American Association of Pharmaceutical Scientists PharmSciTech, 11(3). https://doi.org/10.1208/s12249-010-9479-8

Shimada, T., \& Hasegawa, T. (2017). Determination of equilibrium structures of bromothymol blue revealed by using quantum chemistry with an aid of multivariate analysis of electronic absorption spectra. Spectrochimica Acta Part A: Molecular and Biomolecular Spectroscopy, 1-31. https://doi.org/10.1016/j.saa.2017.05.040

Smith, P. T., King, A. D., \& Goodman, N. (2009). Isolation and characterization of urease from Aspergillus niger. Journal of General Microbiology. https://doi.org/10.1099/00221287139-5-957

Tiwari, A., Aryal, S., Pilla, S., \& Gong, S. (2009). Talanta An amperometric urea biosensor based on covalently immobilized urease on an electrode made of hyperbranched polyester functionalized gold nanoparticles. Talanta, 78, 1401-1407. https://doi.org/10.1016/j.talanta.2009.02.038

Velychko, T. P., Soldatkin, O. O., Melnyk, V. G., Marchenko, S. V, Kirdeciler, S. K., Akata, B., \& Soldatkin, A. P. (2016). A Novel Conductometric Urea Biosensor with Improved Analytical Characteristic Based on Recombinant Urease Adsorbed on Nanoparticle of Silicalite. Nanoscale Research Letters, 11, 106. https://doi.org/10.1186/s11671-016-1310-3

Verma, N., Kumar, R., \& Sachin, M. (2012). Simple , qualitative cum quantitative, user friendly biosensor for analysis of Urea. Advances in Applied Science Research, 3(1), 135-141.

Wang, Y. Q., Wang, S. S., Zhu, J., Wang, L., Jiang, B. H., \& Zhao, W. J. (2016). Determination of urea content in urea cream by centrifugal partition chromatography. Journal of Food and Drug Analysis. https://doi.org/10.1016/j.jfda.2015.10.005

Xie, X., \& Suleiman, A. A. (1990). A Urea Fiber Optic Biosensor Based on Absorption Measurement. Analytical Letters, 23(12), 2143-2153. https://doi.org/10.1080/00032719008052556

Zusfahair, Z., Ningsih, D. R., Fatoni, A., \& Santri, D. (2018a). Determination of Urease Biochemical Properties of Asparagus Bean ( Vigna unguiculata ssp sesquipedalis L .) Determination of Urease Biochemical Properties of Asparagus Bean ( Vigna unguiculata ssp sesquipedalis L . ). IOP Conf. Series: Materials Science and Engineering, 349, 19. https://doi.org/10.1088/1757-899X/349/1/012073

Zusfahair, Ningsih, D. R., Fatoni, A., \& Putri, D. (2018). Partial purification and characterization of urease from black-eyed pea ( Vigna unguiculata ssp unguiculata L . ). Malaysian Journal of Fundamental and Applied Sciences, 14(1), 20-24.

Zusfahair, Ningsih, D. R., Fatoni, A., \& Santri, D. (2018b). Pemurnian Parsial dan Karakterisasi Urease dari Biji Kacang Panjang ( Vigna unguiculata subsp sesquipedalis L . ). ALCHEMY Jurnal Penelitian Kimia, 14(1), 72-83. https://doi.org/10.20961/alchemy.14.1.13000.72-83

Zusfahair, Ningsih, D. R., Kartika, D., Fatoni, A., \& Zuliana, A. L. (2017). Bacillus thuringiensis HCB6 Amylase Immobilization by Chitosan Beads. JCC2016 IOP Publishing IOP Conf. Series: Materials Science and Engineering, 172, 1-10. https://doi.org/10.1088/1742-6596/755/1/011001 